\title{
Necrobiosis lipoidica - an old but challenging dermatosis
}

\section{Obumieranie tłuszczowate nadal wyzwaniem terapeutycznym}

\author{
Magdalena Ciążyńska', Igor Bednarski', Joanna Narbutt², Anna Woźniacka², Aleksandra Lesiak² \\ 'Student Research Group at Department of Dermatology, Medical University of Lodz, Lodz, Poland \\ 2Department of Dermatology, Medical University of Lodz, Lodz, Poland
}

Przegl Dermatol 2016, 103, 45-48 DOI: 10.5 | |4/dr.2016.5774|

\section{KEY WORDS:}

necrobiosis lipoidica, differential diagnosis, treatment regimens.

SŁOWA KLUCZOWE:

obumieranie tłuszczowate, diagnostyka różnicowa, schematy lecznicze.

\author{
ADDRESS FOR \\ CORRESPONDENCE: \\ Associate Professor \\ Aleksandra Lesiak \\ Department of Dermatology \\ Medical University of Lodz, \\ Plac Hallera 1 \\ 90-647 Lodz, Poland \\ Phone/fax: +48 426867981 , \\ +48426884565 \\ E-mail: aleksandra.lesiak@ \\ umed.lodz.pl
}

\begin{abstract}
Introduction. Necrobiosis lipoidica (NL) is a rare skin condition associated with diabetes that occurs in $0.3-1 \%$ of diabetic patients. Nevertheless, there are patients who develop this entity in the absence of diabetes mellitus.

Objective. To highlight some problems in differential diagnosis and treatment of NL.

Case report. We report a case of a 44-year-old woman with a 3-year history of undiagnosed skin lesions. Clinical examination revealed atrophic plaques on an erythemal background located on both shins. The first histopathological examination revealed infiltrated granulomatous lesions, later confirmed as deep tuberculoides chronic granulomatous dermatitis. However, after 6-month anti-tubercular treatment skin lesions were still present. Based on another skin biopsy we restricted the diagnosis to polyarteritis nodosa, necrobiosis lipoidica and granuloma annulare. Further examination led us to establish a diagnosis of necrobiosis lipoidica. The patient was treated with many therapeutic regimens without a satisfactory response.

Conclusions. Lack of treatment guidelines and therapy based on dermatologists' clinical experience suggest that NL needs to be evaluated in the near future. A large retrospective study and systematic review are required to establish diagnostic and treatment regimens.
\end{abstract}

\section{STRESZCZENIE}

Wprowadzenie. Obumieranie tłuszczowate (necrobiosis lipoidica - NL) jest rzadką dermatozą współwystępującą w 0,3-1\% z cukrzycą, jednak obecność cukrzycy nie jest obligatoryjna.

Cel pracy. Podkreślenie problemów w diagnostyce różnicowej i leczeniu NL.

Opis przypadku. Przedstawiamy przypadek 44-letniej kobiety, u której zmiany skórne pozostawały nierozpoznane przez 3 lata. $W$ badaniu przedmiotowym stwierdzono zanikowe zmiany na podłożu rumieniowym zlokalizowane na obu podudziach. Pierwsze badanie histopatologiczne wykazało nacieczone, ziarniniakowate zmiany o charakterze dermatitis chronica granulomatosa profunda tuberculoides, jednak 6-miesięczne leczenie przeciwgruźlicze nie przyniosło rezultatów. Na podstawie kolejnych badań histopatologicznych zawężono diagnozę do guzkowego zapalenia tętnic, NL i ziarniniaka obrączkowatego. Po po- 
braniu następnej biopsji potwierdzono diagnozę NL. U pacjentki zastosowano wiele metod leczenia bez zadowalających rezultatów.

Wnioski. Brak jednoznacznych wytycznych, a także dane z piśmiennictwa sugerują konieczność prowadzenia dalszych badań w celu ustalenia postępowania diagnostyczno-terapeutycznego $u$ chorych na NL.

\section{INTRODUCTION}

Necrobiosis lipoidica (NL) is chronic granulomatous disease involving both dermis and subcutaneous tissue, first described in 1929 by Oppenheim [1]. Necrobiosis lipoidica presents as indolent shiny plaques in most cases localized on lower extremities. Usually, the disease progresses from red-brown telangiectatic lesions to atrophic, depressed and sclerotic plaques. It is considered that NL occurs mainly in diabetic patients, but there is increasing evidence about its concomitance with sarcoidosis, connective tissue diseases (CTD) and inflammatory bowel diseases (IBD) [2-4]. Based on data from the literature, about $75 \%$ of NL patients also suffer from diabetes mellitus (DM) [5], but NL occurs in only $0.3-1 \%$ of diabetic patients [6]. The association between NL and DM remains equivocal; there are still patients who develop these lesions in absence of DM. The histopathological picture of NL demonstrates an inflammatory process with granuloma formation, degeneration of collagen and thickening of endothelium. Granulomas, composed predominantly of lymphocytes and histiocytes with occasional plasma cells and eosinophils, are arranged in a layered fashion. Reduction of intradermal nerves and perivascular lymphocyte

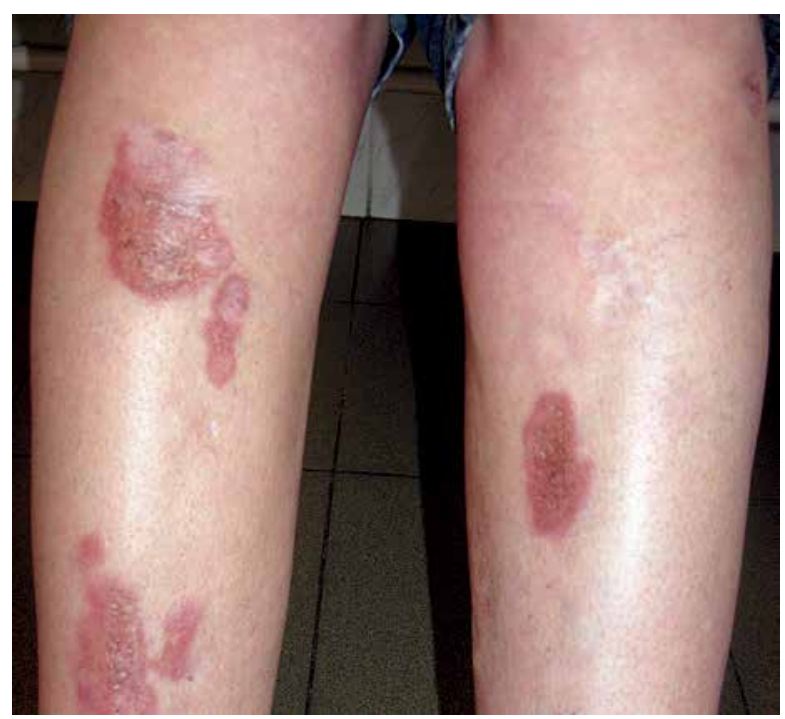

Figure I. Clinical picture before therapy

Rycina I. Obraz kliniczny przed rozpoczęciem pienwszej terapii concentration is a supplementary feature of NL [7]. The pathogenesis of NL remains unknown, although many investigators have considered diabetic microangiopathy. Other conceptions about development of NL include immunoglobulin deposition in the endothelium and platelet aggregation dysfunction [7, 8]. Słowik-Kwiatkowska et al. [9] demonstrated that increased tumor necrosis factor (TNF)- $\alpha$ production in NL leads to impaired angiogenesis, which results in microangiopathy. There are also no guidelines about treatment of NL; immunosuppressive drugs such as cyclosporine, corticosteroids and antimalarials are not always effective, but there is increasing evidence that phototherapy combined with psoralen administration (PUVA) is efficient [10].

\section{OBJECTIVE}

In this article we present a case of NL which was very challenging in both diagnosis and treatment.

\section{CASE REPORT}

The 44-year-old woman was admitted to our hospital with a 3-year history of skin lesions (fig. 1). Six months before admission, the diagnosis of deep tuberculoides chronic granulomatous infiltrate based on histopathological findings, was established, and in that time she was treated with isoniazid and rifampicin without the expected improvement. During the first hospitalization clinical examination revealed slightly painful red-brown atrophic plaques with visible blood vessels located on both shanks. Some small areas showed crusting and superficial ulceration. The histopathological analysis suggested the diagnosis of necrobiosis lipoidica. We decided to administer phototherapy combined with psoralen, but 72 cycles of PUVA bath did not bring a satisfactory effect. The next pathological examination revealed the presence of granulomas and fibrosis in the dermis, accompanied by an inflammatory infiltrate. The diagnosis suggested chronic granulomatous dermatitis, which could be observed in sarcoidosis, tuberculosis or necrobiosis lipoidica; nevertheless, the chest X-ray did not indicate any disorder. We 
performed polymerase chain reaction, but mycobacterial DNA was not detected in biopsy specimens. Then, we started dapsone therapy (100 mg per day), which resulted in blanching and flattening of skin lesions and healing of minor ulcerations (fig. 2). After 2 months of dapsone therapy, side effects from the gastrointestinal tract (nausea, mucous erosion and oral dryness) and paresthesias on both legs were observed, so it was discontinued. Additionally, atrophic plaques were enlarged again and new skin changes were noticed. The third pathological examination revealed perivascular macrophage infiltration and focal necrobiosis, with the suggestion of polyarteritis nodosa, necrobiosis lipoidica or granuloma annulare. We decided to include cyclosporine therapy in a dose of $300 \mathrm{mg}$ per day. The performed venereal disease research laboratory test (VDRL) and anti-nuclear antibody levels were both negative, and other laboratory examination results were within normal limits. Skin changes were still painful and without any signs of clinical remission. Lack of improvement in the patient's condition resulted in the fourth biopsy, which clearly suggested necrobiosis lipoidica. Cyclosporine therapy was replaced by methylprednisolone and pentoxifylline, but no significant remission of skin lesions was observed, although the patient reported reduction of pain. The patient remains under observation in an outpatient clinic, but after various therapies we did not achieve clinical remission (fig. 3).

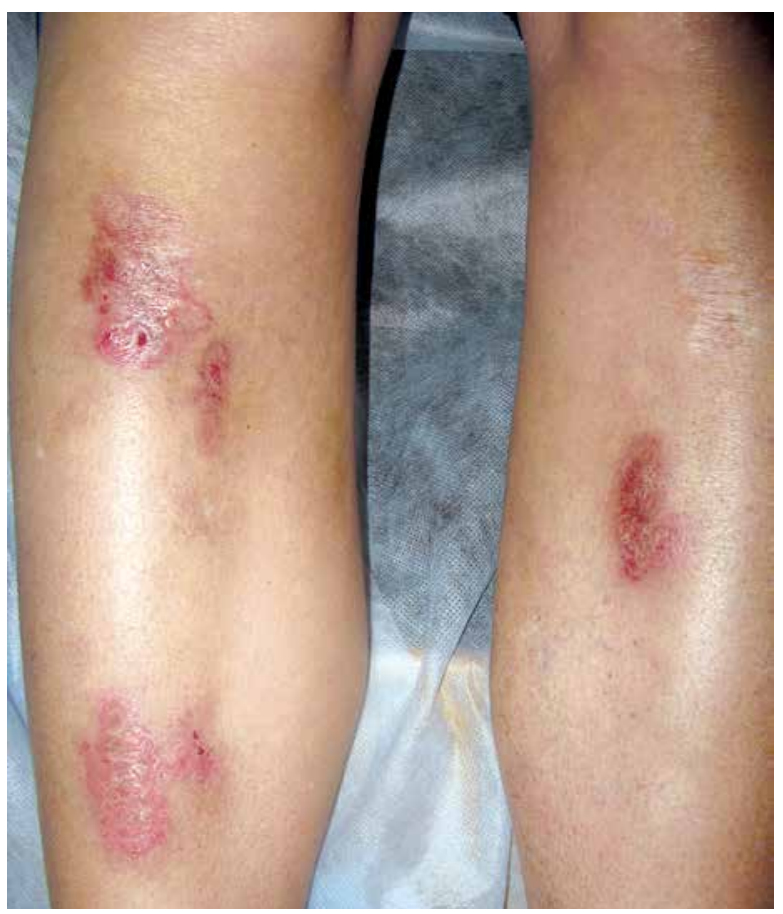

Figure 2. Partial clinical improvement after dapson therapy

Rycina 2. Częściowa poprawa stanu pacjentki po zastosowaniu dapsonu

\section{DISCUSSION}

Necrobiosis lipoidica is an idiopathic dermatological condition, and very few studies have been conducted in order to establish its pathogenesis. The age of onset varies between infancy and late adulthood, and in most cases NL occurs in the third decade [11]. Necrobiosis lipoidica also has a sex predilection, being three times more common in women than in men [11]. One of the main problems with NL is its clinical similarity to other skin conditions: morphea, sarcoidosis and granuloma annulare [12]. Both morphea and NL can present as isolated yellow patches on sclerotic skin, but NL can be distinguished from morphea by telangiectasias around the lesions. In the case of sarcoidosis, cutaneous symptoms range from nodules and rashes to erythema nodosum. Skin atrophy occurs rather rarely, but in our case the absence of radiological abnormalities excluded sarcoidosis from the differential diagnosis. In the early form of necrobiosis lipoidica, superficial annular lesions can resemble granuloma annulare, as in our case [12]. These data indicate that the diagnosis of NL is time consuming. In our case the final diagnosis was established after four biopsies.

Treatment of necrobiosis lipoidica is challenging and usually marginally effective. Previously, we reported effectiveness of PUVA therapy in NL [10]. After a series of sessions we observed remission of skin lesions in some cases. Despite our promising

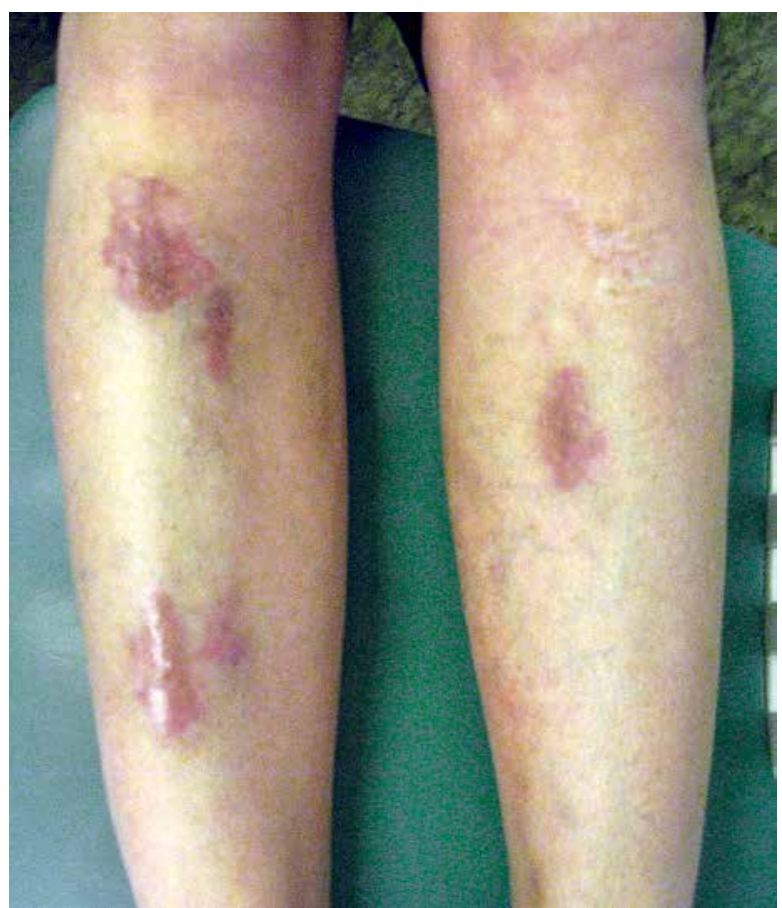

Figure 3. Clinical picture after all therapies

Rycina 3. Obraz kliniczny po zastosowaniu wszystkich opisanych terapii 
results, in the reported case long-term photochemotherapy did not bring any improvement. The presence of inflammatory infiltrate in examined skin specimens was the reason why dapsone was introduced as a new treatment modality. Anti-inflammatory properties of dapsone could explain some regression of the lesions in our case, but this therapy should be discontinued because of side effects. Literature data indicate effectiveness of cyclosporine $\mathrm{A}$ in the treatment of NL [13]. In the present case 3 months of treatment with cyclosporine A did not bring sufficient improvement or even slight pain reduction.

Systemic and topical treatment with corticosteroids is one of the most widely used therapies in the treatment of NL, but in our case long-term therapy with methylprednisolone has not brought detectable clinical improvement. Nevertheless, Petzelbauer et al. [14] described successful 5-week systemic corticosteroid therapy with complete regression of skin lesions and no recurrence within 7 months after treatment. Also, vascular drugs are widely used in therapy of NL. Basaria and Braga-Basaria [15] and Littler and Tschen [16] reported successful treatment of NL with pentoxifylline, but in our case it was ineffective.

\section{CONCLUSIONS}

Despite a thorough diagnostic process including numerous histopathological examinations and laboratory tests, the diagnosis of NL was significantly delayed. Lack of treatment guidelines is also another problem, so the applied therapy is mainly based on dermatologists' clinical experience. Good outcomes achieved by other doctors were not confirmed in our case. We present this case report as it was challenging both in differential diagnosis and treatment.

\section{Conflict of interest}

The authors declare no conflict of interest.

Received: 3 VIII 2015

Accepted: 6 X 2015

\section{References}

1. Korber A., Dissemond J.: Necrobiosis lipoidica diabeticorum. CMAJ 2007, 177, 1498.

2. Mendoza V., Vahid B., Kozic H., Weibel S.: Clinical and pathologic manifestations of necrobiosis lipoidica-like skin involvement in sarcoidosis. Joint Bone Spine 2007, 74, 647-649.

3. Magro C.M., Crowson A.N., Regauer S.: Granuloma annulare and necrobiosis lipoidica tissue reactions as a manifestation of systemic disease. Hum Pathol 1996, 27, 50-56.

4. Jabbour S.A.: Cutaneous manifestations of endocrine disorders: a guide for dermatologists. Am J Clin Dermatol 2003, 4, 315-331.

5. Haralambous S., Blackwell C., Mappouras D.G., Weir D.M., Kemmet D., Lymberi J. i inni: Increased natural autoantibody activity to cytoskeleton proteins in sera from patients with necrobiosis lipoidica, with or without insulin-dependent diabetes mellitus. Autoimmunity 1995, 20, 267-275.

6. Lowitt M.H., Dover J.S.: Necrobiosis lipoidica. J Am Acad Dermatol 1991, 25, 735-748.

7. Peyrí J., Moreno A., Marcoval J.: Necrobiosis lipoidica. Semin Cutan Med Surg 2007, 26, 87-89.

8. Muller S.A., Winkelmann R.K.: Necrobiosis lipoidica diabeticorum histopathologic study of 98 cases. Arch Dermatol 1966, 94, 1-10.

9. Słowik-Kwiatkowska I., Lesiak A., Woźniacka A., SysaJędrzejowska A., Narbutt J.: Does inflammation play a role in development of necrobiosis lipoidica? Przegl Dermatol 2014, 101, 187-191.

10. Narbutt J., Torzecka J.D., Sysa-Jedrzejowska A., Zalewska A.: Long-term results of topical PUVA in necrobiosis lipoidica. Clin Exp Dermatol 2006, 31, 65-67.

11. Verrotti A., Chiarelli F., Amerio P., Morgese G.: Necrobiosis lipoidica diabeticorum in children and adolescents: a clue for underlying renal and retinal disease. Pediatr Dermatol 1995, 12, 220-223.

12. Schwartz M.E.: Necrobiosis lipoidica and granuloma annulare. Simultaneous occurrence in a patient. Arch Dermatol 1982, 118, 192-193.

13. Stanway A., Rademaker M., Newman P.: Healing of severe ulcerative necrobiosis lipoidica with cyclosporin. Australas J Dermatol 2004, 45, 119-122.

14. Petzelbauer P., Wolff K., Tappeiner G.: Necrobiosis lipoidica: treatment with systemic corticosteroids. Br J Dermatol 1992, 126, 542-545.

15. Basaria S., Braga-Basaria M.: Pentoxifylline for necrobiosis lipoidica diabeticorum. J Endocrinol Invest 2003, 26, 10371040.

16. Littler C., Tschen E.H.: Pentoxifylline for necrobiosis lipoidica diabeticorum. J Am Acad Dermatol 1987, 17, 314-316. 